\title{
Core Components for Infection Prevention and Control Programs: A World Health Organization Network Report
}

\author{
Wing Hong Seto, MD; Fernando Otaíza, MD; Carmen L. Pessoa-Silva, MD; \\ World Health Organization Infection Prevention and Control Network
}

\begin{abstract}
Under the leadership of the World Health Organization (WHO), the core components necessary for national and local infection prevention and control programs are identified. These components were determined by a network of international experts who are representatives from WHO regional offices and relevant WHO programs. The respective roles of the national authorities and the local healthcare facilities are delineated.
\end{abstract}

Infect Control Hosp Epidemiol 2010; 31(9):948-950

Healthcare-associated infections occur worldwide, affecting all healthcare facilities in all countries irrespective of the countries' degree of development and causing morbidity, mortality, and excess cost of care. Outbreaks of healthcare-associated infection not only affect hospitals but also can lead to outbreaks in the community, as shown by the pandemic of severe acute respiratory syndrome. Among many important lessons learned in the epidemics of severe acute respiratory syndrome is that healthcare settings can act as amplifiers of disease. Preparation and an ongoing culture of safe healthcare practices that can prevent and control pathogen dissemination are key to coping with outbreak situations.

The implementation of the International Health Regulations $^{1}$ is relevant for protection against the international spread of disease and is an essential element for the early detection and containment of events that may constitute a public health emergency of international concern. Healthcare facilities are the front line of disease detection and control activities. To enable an early public health response to infectious threats, hospital-based surveillance must be developed and must be formally linked to public health surveillance systems. Likewise, infection control practices must be in place for containment purposes.

Organizing an infection prevention and control (IPC) program is critical, because many healthcare-associated infections are preventable by sustainable cost-effective means. An IPC program is an important element of preparation for pandemics of infectious disease.

A meeting was convened in 2008 with experts from 4 con- tinents, who represent 4 World Health Organization (WHO) regional offices and relevant WHO health programs, to identify the core components for the development of effective IPC programs at national and hospital levels and related research priorities. Because of the lack of updated publications on the impact of the different elements of a program on the rates of healthcare-associated infection, the group reflected on the experience of several national initiatives as a primary source for guidance. The core components were identified, and the roles of both the national authorities and the local healthcare facilities were described. ${ }^{2}$ To our knowledge, the present effort to delineate these roles and to integrate them is the first to do so, because the few previous standards published by professional societies, accreditation agencies, or other groups have addressed only the programs in individual healthcare facilities. ${ }^{3,4}$ The following 8 core components were identified:

1. Organization of IPC programs: a formal structure responsible for the program, including its policies, goals, and strategies.

2. Guidelines: development, dissemination, and implementation of evidence-based IPC guidelines for the relevant risks (a basic set is recommended in Table 1).

3. Human resources: provision of adequate staff and training in IPC activities, the addressing of biological risks for staff, and the implementation of preventive measures.

4. Surveillance of infections and assessment of compliance with IPC practices: the establishment of appropriate 
TABLE 1. Infection Prevention and Control (IPC) Core Components and Respective Roles of National and Local Levels

\begin{tabular}{|c|c|c|}
\hline \multirow[b]{2}{*}{ IPC component } & \multicolumn{2}{|c|}{ Actions } \\
\hline & National health authority level & Local HCF level \\
\hline Organization of IPC programs & $\begin{array}{l}\text { Nationwide authority with qualified staff, scope, } \\
\text { functions, and budget. } \\
\text { Ensuring of the preparedness and coordination } \\
\text { of IPC elements for communicable diseases. }\end{array}$ & $\begin{array}{l}\text { Designated leadership and authority for HCF } \\
\text { program with dedicated and qualified staff, } \\
\text { clear scope and functions, and adequate } \\
\text { budget. } \\
\text { Responsibility for HCF preparedness and re- } \\
\text { sponse to communicable disease emergencies. }\end{array}$ \\
\hline Technical guidelines ${ }^{\mathrm{a}}$ & $\begin{array}{l}\text { Development and dissemination of guidelines } \\
\text { for prevention and management of infections. }\end{array}$ & $\begin{array}{l}\text { Adaptation and implementation at the local } \\
\text { level. }\end{array}$ \\
\hline Human resources & $\begin{array}{l}\text { Definition of contents for training of HCWs } \\
\text { and IPC professionals. } \\
\text { Standards for adequate staffing. } \\
\text { Addressing of biological risks for staff. }\end{array}$ & $\begin{array}{l}\text { Basic training of all HCWs. } \\
\text { Access to specialized training for IPC } \\
\text { professionals. } \\
\text { Provision of adequate staff. } \\
\text { Prevention of biological risks. }\end{array}$ \\
\hline $\begin{array}{l}\text { Surveillance and assessment of } \\
\text { compliance with IPC } \\
\text { practices }\end{array}$ & $\begin{array}{l}\text { National coordination; definition of objectives, } \\
\text { priorities, and nature of data; and reporting } \\
\text { to interested parties. } \\
\text { Standardized case definitions and surveillance } \\
\text { methods. } \\
\text { Promotion of assessment of IPC practices and } \\
\text { other relevant processes in a blame-free insti- } \\
\text { tutional culture. }\end{array}$ & $\begin{array}{l}\text { Assessment of the local situation. } \\
\text { Definition of local objectives, priorities, and } \\
\text { survey methods. } \\
\text { Appropriate surveillance (according to the local } \\
\text { needs) and reporting. } \\
\text { Assessment of compliance with IPC practices. }\end{array}$ \\
\hline Microbiology laboratory & $\begin{array}{l}\text { Standardized laboratory techniques. } \\
\text { Promotion of interactions with laboratory. } \\
\text { Defined biosafety standards. }\end{array}$ & $\begin{array}{l}\text { Access to laboratory service. } \\
\text { Liaison between the laboratory and IPC } \\
\text { activities. } \\
\text { Implementation of biosafety standards. }\end{array}$ \\
\hline Environment & $\begin{array}{l}\text { Definition of the minimum requirements for } \\
\text { IPC purposes. }\end{array}$ & $\begin{array}{l}\text { Assessment and management of infection risks } \\
\text { in the environment }\end{array}$ \\
\hline $\begin{array}{l}\text { Monitoring and evaluation of } \\
\text { programs }\end{array}$ & $\begin{array}{l}\text { Establishment of a mechanism for regular mon- } \\
\text { itoring and reporting of HCF IPC programs. } \\
\text { Promotion of nonpunitive culture. }\end{array}$ & $\begin{array}{l}\text { Regular monitoring. } \\
\text { Regular reports on state of local programs. } \\
\text { Promotion of nonpunitive culture. }\end{array}$ \\
\hline $\begin{array}{l}\text { Link with public health and } \\
\text { other services }\end{array}$ & $\begin{array}{l}\text { Definition of procedures for links and } \\
\text { communications. }\end{array}$ & $\begin{array}{l}\text { Establishment of links and representation of } \\
\text { IPC in public health activities. }\end{array}$ \\
\hline
\end{tabular}

NoTE. HCF, healthcare facility; HCW, healthcare worker.

a basic set of technical guidelines should include isolation precautions (standard and additional precautions), aseptic technique for clinical procedures, waste management, and staff health.

surveillance methods and priorities, including outbreak detection and prompt response.

5. Microbiology laboratory: the standardization of microbiology laboratory techniques, the promotion of interaction of the laboratory with IPC activities (ie, surveillance), and the establishment of laboratory biosafety standards.

6. Environment: at a minimum, clean water, ventilation, hand-washing facilities, patient placement and isolation facilities, storage of sterile supplies, and clear conditions for building and renovation.

7. Monitoring and evaluation of IPC programs: regularly conducted evaluation with reporting of outcomes, processes, and strategies at the national and local levels as well as promotion of a nonpunitive culture in the evaluation exercise.
8. Coordination: links with public health and other services for events of mandatory reporting and coordination of activities related to waste management, sanitation, biosafety, antimicrobial pharmacy, occupational health, patients and consumers, and healthcare quality.

In Table 1, the respective roles for the national authorities and the local healthcare facilities are presented. In the meeting, the following research priorities were also identified.

1. Skills and curriculum for training of IPC professionals.

2. The optimum ratio of IPC professionals to workload.

3. Strategies for implementation of new IPC programs.

4. Applicability of the core components to different types of facilities and settings.

We expect that our definition of core components for IPC programs will be useful for countries and local facilities in strengthening or initiating IPC programs. Also the document 
may help in the assessment of IPC programs. Currently, the principles outlined in this document are being tested in some countries. The testing may help provide local data on resources required and feasibility and will inform future policies.

\section{WORLD HEALTH ORGANIZATION}

\section{INFECTION PREVENTION AND CONTROL}

\section{NET WORK}

The members of the World Health Organization Infection Prevention and Control Network, in alphabetical order, are Michael Bell, Richard Brown, Yves Chartier, Meena Nathan Cherian, Ana Paula Coutinho, Reuben Granich, Kathleen Anne Holloway, Selma Khamassi, Jian Li, Mamunur Rahman Malik, Ziad A. Memish, Cathryn Murphy, Fernando Otaíza, Shirley Paton, Carmen L. Pessoa-Silva, Rose Wong Pray, Nicoletta Previsani, Pilar Ramon-Pardo, Sharon Salmon, Fabio Scano, Wing Hong Seto, Julie Storr, Susan Wilburn, Celia Woodfill, Martin Yagui, and Junping Yu.

\section{ACKNOWLEDGMENTS}

Potential conflicts of interest. All authors report no conflicts of interest relevant to this article.

Address reprint requests to Wing Hong Seto, MD, Department of Quality and Risk Management, Queen Mary Hospital, 102 Pokfulam Road, Hong Kong (whseto@ha.org.hk).

\section{REFEREN CES}

1. World Health Organization (WHO). International Health Regulations (IHR). 2nd ed. Geneva, Switzerland: WHO, 2005. http://www.who.int/ ihr/en/. Accessed February 2, 2010.

2. World Health Organization (WHO). Core components for infection prevention and control programmes. http://www.who.int/csr/resources/ publications/WHO_HSE_EPR_2009_1/en/index.html. Updated 2010. Accessed February 2, 2010.

3. Scheckler WE, Brimhall D, Buck AS, et al. Requirements for infrastructure and essential activities of infection control and epidemiology in hospitals: a consensus panel report. Society for Healthcare Epidemiology of America. Infect Control Hosp Epidemiol 1998;19:114-124.

4. Rasslan $O$, Heeg P. Infection prevention and control program organization structure. In: Friedman C, Newsom W, eds. IFIC Basic Concepts of Infection Control. Northern Ireland, United Kingdom: International Federation of Infection Control (IFIC), 2007. 